\title{
Blackberry Vinegar Produced By Successive Acetification Cycles: Production, Characterization And Bioactivity Parameters
}

\author{
Mário Antônio Alves da Cunha ${ }^{1 *}$, Kely Priscila de Lima ${ }^{1}$, Vidiany Aparecida Queiroz \\ Santos $^{1}$, Otto Lucas Heinz ${ }^{1}$, Carla Adriana Pizarro Schmidt ${ }^{2}$. \\ ${ }^{1}$ Universidade Tecnológica Federal do Paraná, Departamento de Química, Pato Branco, Paraná, Brasil. \\ ${ }^{2}$ Universidade Tecnológica Federal do Paraná, Departamento de Engenharia de Produção, Medianeira, Paraná, \\ Brasil.
}

\begin{abstract}
Blackberry vinegar was produced in successive acetification cycles and content of total phenolics, anthocyanins and antioxidant activity were evaluated along the production. Firstly, blackberry wine was obtained in bench-scale bioreactor, being verified $0.39 \mathrm{~g} / \mathrm{g}$ ethanol yield, $1.78 \mathrm{~g} / \mathrm{L} . \mathrm{h}$ volumetric productivity and $76 \%$ efficiency. After, three successive acetification cycles were conducted efficiently in grapia barrel with average acetic acid production of 51.6 $\mathrm{g} / \mathrm{L}, 72.2 \%$ acetic acid yield and $0.4 \mathrm{~g} / \mathrm{L}$.h volumetric productivity. Appreciable contents of polyphenolic compounds, anthocyanins and high antioxidant activity were observed in the raw material, wine and vinegar obtained in each cycle of acetic acid transformation. Acetic acid transformation led the small reduction of antioxidant activity compared to alcoholic fermentation, but the antioxidant potential was maintained along the cycles. The content of total phenolics and anthocyanins also suffered a reduction in step of acetification.
\end{abstract}

Keywords: Berries, Acetic Acid Bacteria, Bioactives, Wine, Fermentation.

${ }^{1}$ Authors for correspondence: mcunha@utfpr.edu.br 


\section{INTRODUCTION}

The production and consumption of berries has presented considerable growth in recent years, due to the increase in the interest of the consumers by nutritional benefits and functional, both of in natura fruit as the products processed the basis of berries (1).

Blackberry is one of the berries with more consumption in Brazil and in the world due to the peculiar taste, benefits to health and yet by the low calorific value ( $\cong 11 \mathrm{kcal} / 100 \mathrm{~g}$ ) (2). The fruit is rich in vitamin $C$ and mineral salts such as selenium, iron, calcium, magnesium, potassium and phosphorus, which are indispensable to the proper functioning of the organism. In addition, blackberry presents high content of polyphenols, ellagitannins, anthocyanins and antioxidant activity, when compared to other berries (3).

The consumption of blackberries has beneficial effects on the physical and mental health, especially due to the antioxidant potential of the anthocyanins and phenolic compounds present in large quantities in the fruit. Between the beneficial effects to health can be mentioned the protection against free radicals; reduction the risk of development of cardiovascular and coronary diseases; prevention of degenerative diseases; anti carcinogenic and antiinflammatory effects $(4,5)$.

The high post-harvest respiration rate and the fragility of the fruits reduces useful life, besides the fruit is quite susceptible to deterioration, mainly from fungal origin. In this way, products based on blackberry as frozen pulps, jellies, juices, ice cream, yogurt and teas are found with greater ease than the in natura fruit on the market $(6,7)$.

The transformation of the fruit into wine and gourmet vinegar can be a good strategy for value aggregation and the strengthening of the productive chain. Wine and vinegar obtained from blackberries constitute products that allow and facilitate the consumption and use of bioactive compounds present in the fruit. Furthermore, the wide diversity of products containing vinegar such as sauces, ketchup, mayonnaise among others has stimulated the industrial production of this product (8).

In this context, the present work studied the processes of alcoholic fermentation and acetic oxidation conducted in (Brazilian gold wood) grapia barrel through successive cycles of acetic acid transformation. The wine and vinegar produced were characterized by physical-chemical parameters of quality, total phenolics content, anthocyanins and antioxidant activity. In addition, the total phenolics content, anthocyanins and the antioxidant potential of in natura fruit, wine and vinegar were compared among themselves.

\section{MATERIALS AND METHODS}

\section{Raw material and process of bioactive compounds extraction}

Blackberry (Rubus sp. var. guarani) was acquired from the farm producing fruits located at Southwest region of Paraná, Brazil. The fruits were kept frozen $\left(-18{ }^{\circ} \mathrm{C}\right)$ until processing.

Anhydrous ethanol and acetone were evaluated as extracting agents of phenolic compounds and antioxidants of fruit. Blackberries in natura were triturated and submitted to extraction with the extracting agent in Erlenmeyer flasks using the proportion of $5 \mathrm{~g}$ of fruit for $20 \mathrm{~mL}$ of solvent. The flasks were kept at $25^{\circ} \mathrm{C}$ under stirring of $150 \mathrm{rpm}$ for 5 minutes in rotatory shaker. The extracts were separated from the pulp and skins by filtering on filter paper and employed in analyzes of total phenolics, anthocyanins and antioxidant activity.

\section{Microorganisms and inoculums cultivation}

Saccharomyces cerevisiae f.r. bayanus (Fermol, Perlage, AEB Biochemistry Latin American SA) was cultivated in malt extract medium $(20 \mathrm{~g} / \mathrm{L}$ malt extract, $1 \mathrm{~g} / \mathrm{L}$ peptone and $20 \mathrm{~g} / \mathrm{L}$ glucose) for $24 \mathrm{~h}$ $\left(120 \mathrm{rpm}, 28^{\circ} \mathrm{C}\right)$. The yeast cells were recovered from the medium by centrifugation $(1350 \mathrm{x} \mathrm{g}, 30$ min.) and re-suspended in saline solution $(0.9 \%$ $\mathrm{w} / \mathrm{v})$. Standardized pre-inoculum containing $2 \times 10^{6}$ cells $/ \mathrm{mL}$ was employed in the alcoholic fermentation process.

Mixed culture of acid acetic bacteria was isolated from colonial red grapes vinegar (non-pasteurized). GY medium (10\% glucose, $1 \%$ yeast extract and $100 \mathrm{mg} / \mathrm{L}$ natamycin) was employed in the process of acetic culture selection and insolation. A volume of $10 \mathrm{~mL}$ of non-pasteurized vinegar was transferred for Erlenmeyer flasks containing 100 $\mathrm{mL}$ of GY medium and incubated for $48 \mathrm{~h}$ at $30^{\circ} \mathrm{C}$ and $120 \mathrm{rpm}$. Acetic culture was recovered by centrifugation ( $1350 \mathrm{x} \mathrm{g}, 30 \mathrm{~min})$ and resuspended in physiological saline solution $(0.9 \% \mathrm{w} / \mathrm{v})$ until obtaining a solution with $0.5 \mathrm{~nm}$ optical density at 
$600 \mathrm{~nm}$. Inoculum was prepared by the mixture of $25 \mathrm{~mL}$ culture acetic and $155 \mathrm{~mL}$ blackberry wine in $250 \mathrm{~mL}$ Erlenmeyer flasks. The flasks were kept in orbital shaker for $24 \mathrm{~h}$ at $30{ }^{\circ} \mathrm{C}$ and $120 \mathrm{rpm}$ for growth and cell adaptation.

\section{Alcoholic fermentation and acetic oxidation}

Blackberry fruits were slowly thawed under refrigeration, and then depulped in multiprocessor and passed through (mesh $0.5 \mathrm{~mm}$ ) stainless steel sieve for removal of seeds and part of husks. Content of soluble solids was corrected to $18^{\circ} \mathrm{Brix}$ with commercial sucrose. The must was then supplemented $(30 \mathrm{~g} / \mathrm{hl})$ by the addition of yeast growth activator $\left(\right.$ ENOVIT $^{\circledR}$, Pascal Biotech, France) and sulphited by addition of $50 \mathrm{mg} / \mathrm{L}$ of sodium metabisulphite.

Pre-inoculum of $S$. cerevisae $\left(35 \mathrm{~mL}, 2 \times 10^{6}\right.$ cells $/ \mathrm{mL}$ ) was transferred to $5 \mathrm{~L}$ fermentation vessel containing $315 \mathrm{~mL}$ of most and cultivated in benchscale bioreactor (Biostat B, B. Braun Melsungen, Germany) for $24 \mathrm{~h}$ at $28{ }^{\circ} \mathrm{C}$. The alcoholic fermentation was initiated by the addition of 3150 $\mathrm{mL}$ of must to bioreactor containing adapted inoculum and conducted at $28^{\circ} \mathrm{C}$.

Blackberry wine $(1620 \mathrm{~mL})$ obtained from alcoholic fermentation was supplemented with Acetozym ${ }^{\circledR}$ (Heinrich Frings GmbH \&AMP; Co, USA), transferred to grapia barrel (Brazilian gold wood) and inoculated with $180 \mathrm{~mL}$ of inoculum. The inoculated wine was maintained at $30^{\circ} \mathrm{C}$ in cell culture incubator. Were conducted three successive cycles of acetic acid transformation with withdrawal of $65 \%$ of the vinegar produced and addition of an equal volume of wine to each cycle (acidity between 4.0-4.5\%). Vinegars produced were centrifuged ( $1350 \mathrm{x} \mathrm{g}$, for 30 minutes), filtered on filter paper, bottled and pasteurized for later characterization.

\section{Physical-chemical characterization and bioactivity parameters}

Blackberry was characterized as regards the content of lipids (Soxhlet extraction method), crude protein (Kjeldahl method), mineral residue (incineration at $550{ }^{\circ} \mathrm{C}$ ), crude fiber, moisture (kiln-drying method at $105{ }^{\circ} \mathrm{C}$ ), total soluble solids (hand refratometer), $\mathrm{pH}$, titratable acidity (titrimetric method) according the Association of Official Methods of Analytical Chemists (9). Total reducing sugars was determined by DNS method after hydrolisys with $\mathrm{HCl} 1 \mathrm{~mol} / \mathrm{L}$ (10), total phenolic compounds by spectrophotometric Folin-Ciocalteau method (11), total anthocyanins content by $\mathrm{pH}$ differential method (12) and antioxidant activity using DPPH method (13) and $\mathrm{ABTS}^{+}$cation radical discoloration assay (14).

The wine and vinegar of blackberry were submitted to analysis of $\mathrm{pH}$, titratable acidity, total soluble solids, density, total and free sulfur dioxide content, total dry extract and reduced, sulphate (9), total reducing sugar (DNS method) and total phenolic compounds, anthocyanins and antioxidant activity as described above. Ethanol and acetic acid were measured by HPLC using refractive index (IR) detector and Bio-Rad HPX-87-H (300 $7.8 \mathrm{~mm}$ ) column at $45^{\circ} \mathrm{C}, 0.005 \mathrm{~mol} / \mathrm{L}$ sulphuric acid the eluent, flow rate of $0.4 \mathrm{~mL} . \mathrm{min}$ ) and sample volume of $20 \mu \mathrm{L}$.

\section{RESULTS AND DISCUSSIONS}

\section{Physical-chemical parameters of blackberry fruits}

The results of the physical-chemical analysis and bioactivity parameters of blackberry samples are shown in Table 1 . The $\mathrm{pH}$ value of fruits was 3.22 and the titratable acidity expressed in citric acid was $1.51 \mathrm{~g} / 100 \mathrm{~g}$. Similar results were described by Souza et al. (15), which found similar physicalchemical characteristics between berries grown in tropical regions of Brazil and berries cultivated in zones with temperate areas.

On the other hand, the moisture content found (58.5 $\mathrm{g} / 100 \mathrm{~g}$ ) in the sample analyzed was lower than that described by these authors, which described values of $87.92 \mathrm{~g} / 100 \mathrm{~g}$. The lower moisture content found is possibly associated with the loss of water by syneresis during thawing of fruits. Low protein content $(1.47 \mathrm{~g} / 100 \mathrm{~g})$ and lipids $(0.21 \mathrm{~g} / 100 \mathrm{~g})$ were also checked and are in concordance with the literature data (15).

Relatively high content of mineral residue (2.17 $\mathrm{g} / 100 \mathrm{~g})$ and fibers $(14.33 \mathrm{~g} / 100 \mathrm{~g})$ were found and such results are associated with the presence of bark and some seeds in the analyzed samples. The content of total reducing sugars was $9.8 \mathrm{~g} / 100 \mathrm{~g}$ and solids soluble content was $9^{\circ} \mathrm{Brix}$, which are within the average values reported by other authors $(16,17)$.

In the literature are reported the use of different solvents for the extraction of polyphenols from fruits, as acidified methanol (18), ethanol (19), acidified ethanol (20); acetone (19) and acidified acetone (17). In this study, ethanol and acetone 
were evaluated as extracting agent of bioactive compounds.

As can be seen in Table 1, in a general way, acetone provided better extraction of phenolic compounds, with an efficiency $73.1 \%$ higher $(1.702 \mathrm{mg}$ $\mathrm{GAE} / 100 \mathrm{~g}$ ) than obtained with the ethanol (983.4 $\mathrm{mg}$ GAE/100g). This behavior was also described by Vizzotto and Pereira (21) and Ubeda et al. (22), which obtained better results of extraction of phenolic compounds of blackberry and strawberries using acetone as extracting agent.

Souza et al. (15) used solution of methanol and water $(50: 50 \mathrm{v} / \mathrm{v})$ for the extraction of phenolic compounds from blackberries and found a maximum content of $850.52 \mathrm{mg}$ GAE$/ 100 \mathrm{~g}$, lower result than that obtained in this work both in extraction with ethanol (983.4 $\mathrm{mg}$ GAE/100g) as with acetone (1.702 mg GAE/100g).

With relation to the levels of total anthocyanins present in fruit, were also verified larger contents when employed the solvent acetone $(511.7 \mathrm{mg}$ cyanidin-3-glucoside/100g) in the protocol of extraction. This content was $28.13 \%$ higher than that obtained with extraction in ethanol $(399.4 \mathrm{mg}$ cyanidin-3-glucoside/100g). In accordance with Siriwoharn and Wrolstad (23) the content of anthocyanins, in particular the cyanidin-3- glucoside that is the majority of the blackberry pigment, varies considerably depending on the stage of maturation of the fruit. These authors reported lower content to the obtained in this study (317 mg cyanidin-3-glucoside/100g).

Similarly to that observed with the total phenolic content and anthocyanins, the solvent employed in the extraction process, influenced the values of $\mathrm{DPPH}$ and $\mathrm{ABTS}^{+}$radical scavenging capacity. Values of $38.5 \mu \mathrm{mol}$ Trolox equivalent $/ \mathrm{g}$ (TE/g) were observed when performed extraction with acetone and $36.01 \mu \mathrm{mol} \mathrm{TE} / \mathrm{g}$ when employed ethanol. Such values statistically differed among themselves $(p<0.05)$, indicating that the acetone promoted better extraction of substances with antioxidant activity measured by the DPPH method. In relation to the antioxidant activity assessed by the $\mathrm{ABTS}^{+}$radical scavenging method, no significant difference was observed in the values obtained with both solvent extractors $(9.43 \mu \mathrm{mol}$ $\mathrm{TE} / \mathrm{g}$ fruit in acetone and $9.16 \mu \mathrm{mol} \mathrm{TE} / \mathrm{g}$ fruit in ethanol). This result suggests that ethanol and acetone showed similar capacity of extraction of antioxidant compounds with similar antioxidant potential measured through this method $\left(\mathrm{ABTS}^{+}\right.$ radical scavenging).

Table 1. Physical-chemical parameters, total phenolics, anthocyanins and antioxidant activity of blackberry fruits.

\begin{tabular}{|c|c|c|}
\hline Physical-chemical parameters & \multicolumn{2}{|c|}{ Observed values } \\
\hline $\mathrm{pH}$ & \multicolumn{2}{|c|}{$3.22 \pm 0.002$} \\
\hline Titratable acidity (g/100g) & \multicolumn{2}{|c|}{$1.51 \pm 0.002$} \\
\hline Moisture (g/100g) & \multicolumn{2}{|c|}{$58.05 \pm 0.70$} \\
\hline Crude protein $(\mathrm{g} / 100 \mathrm{~g})$ & \multicolumn{2}{|c|}{$1.47 \pm 0.49$} \\
\hline Lipid $(g / 100 g)$ & \multicolumn{2}{|c|}{$0.21 \pm 0.03$} \\
\hline Mineral residue (g/100g) & \multicolumn{2}{|c|}{$2.17 \pm 0.11$} \\
\hline Crude fiber $(\mathrm{g} / 100 \mathrm{~g})$ & \multicolumn{2}{|c|}{$14.33 \pm 1.53$} \\
\hline Reducing sugars (g/100g) & \multicolumn{2}{|c|}{$9.81 \pm 0.00$} \\
\hline \multirow[t]{3}{*}{ Total soluble solids ( ${ }^{\circ}$ Brix $)$} & \multicolumn{2}{|c|}{$9.00 \pm 0.00$} \\
\hline & \multicolumn{2}{|c|}{ Extracting solvent } \\
\hline & Acetone & Ethanol \\
\hline Total phenolics (mg GAE/100g) & $1702.0 \pm 7.27^{\mathrm{a}}$ & $983.4 \pm 5.21^{\mathrm{b}}$ \\
\hline $\begin{array}{l}\text { Anthocyanins } \\
\text { (mg cyanidin-3-glucoside/100g) }\end{array}$ & $511.7 \pm 0.0^{\mathrm{a}}$ & $399.4 \pm 0.0^{\mathrm{b}}$ \\
\hline $\begin{array}{l}\text { Antioxidante Activity-DPPH } \\
(\mu \mathrm{mol} \text { TROLOX equivalent/g) }\end{array}$ & $38.5 \pm 0.47^{a}$ & $36.01 \pm 0.51^{\mathrm{b}}$ \\
\hline $\begin{array}{l}\text { Antioxidante Activity- } \text { ABTS }^{+} \\
(\mu \mathrm{mol} \text { TROLOX equivalent/g) }\end{array}$ & $9.43 \pm 0.14^{\mathrm{a}}$ & $9.16 \pm 0.11^{\mathrm{a}}$ \\
\hline
\end{tabular}


GAE: gallic acid equivalent.

\section{Alcoholic fermentation}

The fermentative profile of must based on blackberry pulp is shown in the graph in Figure 1. The yeast used in process has shown high fermentative capacity with ethanol accumulation of $63.9 \mathrm{~g} / \mathrm{L}$ (corresponding to $8.09 \%, \mathrm{v} / \mathrm{v}$ ) after 36 hours of fermentation and $76 \%$ substrate consumption. Similary, Hong-Guang et al (24) reported concentrations of ethanol ranging from 3 to $7.4 \%$ in alcoholic fermented beverage produced from must based on blackberry chaptalized with sucrose $\left(15^{\circ}\right.$ Brix $)$.

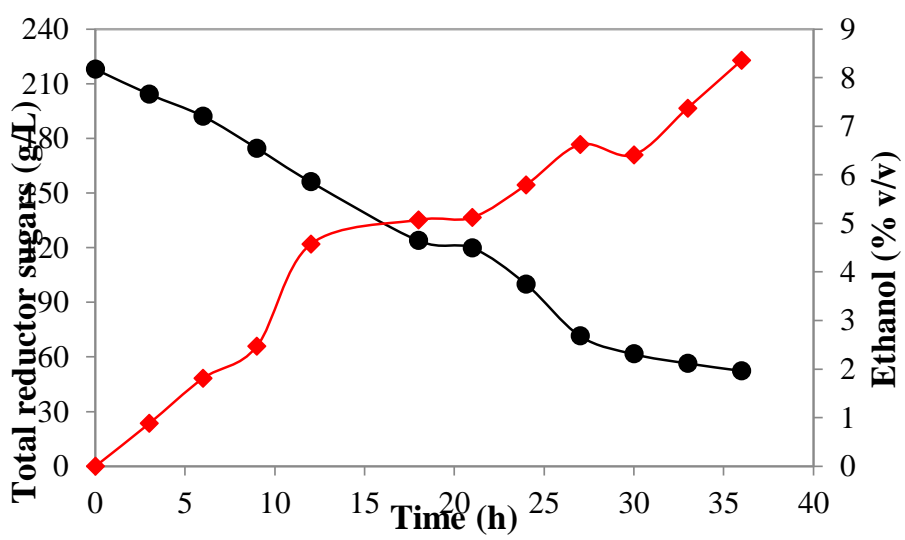

Figure 1 - Content of total reducing sugars $(\bullet)$ and ethanol $(\bullet)$ along the alcoholic fermentation.

Lag phase was not observed in the alcoholic fermentation (Fig. 2). It was observed linear cell growth up to 10 hours of cultivation, which was accompanied by $20 \%$ substrate consumption. The behavior of the yeast related to the consumption of substrate and cellular growth indicates that the same presented good metabolic activity along of fermentation and that the inoculum was adequately prepared and adapted.

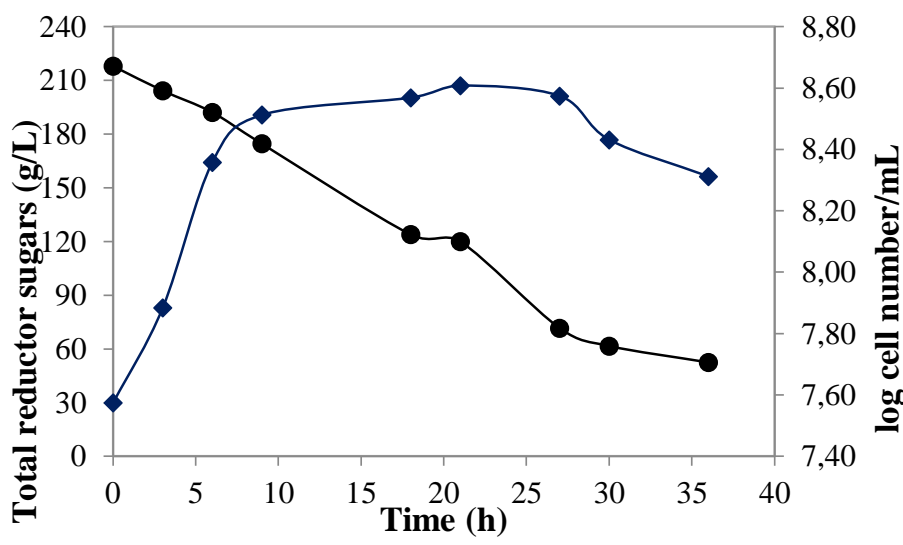

Figure - 2 Content of total reducing sugars $(\bullet)$ and cell concentration $(\bullet)$ along the alcoholic fermentation.

After 36 hours of cultivation there was stabilization of the soluble solids content in fermentation must and stopped the detachment of carbonic gas bubbles, indicating the end of fermentation. In the literature are checked studies that describe the different times of alcoholic fermentation of fruit juices (25-27). Coelho et al. (28) using different fruit for wine production, described the times that varied from $40 \mathrm{~h}$ (cherry) to $190 \mathrm{~h}$ (orange).

At the end of the alcoholic fermentation was verified ethanol yield ( $\mathrm{Y}_{\mathrm{P} / \mathrm{S}}$, ratio between final ethanol concentration and sugar consumption 
during the run) of $0.39 \mathrm{~g} / \mathrm{g}$, volumetric productivity in ethanol $\left(\mathrm{Q}_{\mathrm{P}}\right.$, ratio between final ethanol concentration and fermentation time) of $1.78 \mathrm{~g} / \mathrm{Lh}$, average rate of substrate consumption $\left(\mathrm{Q}_{\mathrm{s}}\right.$, ratio of the glucose consumed to the fermentation time) of $4.6 \mathrm{~g} / \mathrm{Lh}$, efficiency fermentative ( $\mathrm{\eta}$, ratio of the observed ethanol yield to the theoretical yield of ethanol $\left(0.511 \mathrm{g.g}^{-1}\right)$ of $76 \%$ and a substrate consumption percentage of $76 \%$. The incomplete consumption of sugars present in must of fermentation can be associated to the accumulation of ethanol and consequent inhibition of metabolic activity (inhibition by formed product). Another aspect that may have contributed to the permanence of a sugar residual in must is the possible exhaustion of nutrients (mineral and source of nitrogen) along the fermentation, once that were not added nutrients during the fermentation process, but only at the beginning of the process.

\section{Characterization of blackberry wine}

Blackberry wine presented $\mathrm{pH} 3.18$, titratable acidity expressed in acetic acid of $0.92 \mathrm{~g} / 100 \mathrm{~mL}$ and total soluble solids content of $6{ }^{\circ} \mathrm{Brix}$, as described in Table 2. Similar results were described by Oliveira et al. (29) when preparing alcoholic fermented beverage of cagaita (Eugenia dysenterica $\mathrm{DC}$ ), which found $\mathrm{pH}$ value of 3.28 and contents of soluble solids of $5.77^{\circ}$ Brix.

The density of blackberry wine was $1052.8 \mathrm{~g} / \mathrm{L}$. This parameter varies according to the quantity of sugar and ethanol present in fermented. In fact, the blackberry wine presented relatively high content of residual sugars $(52.4 \mathrm{~g} / \mathrm{L})$, which reflected in the density value.

With relation to the content of free and total sulfur dioxide, values observed were of $15.32 \mathrm{mg} / \mathrm{L}$ and $40.96 \mathrm{mg} / \mathrm{L}$, respectively. Such results are in accordance with the limits recommended by the Brazilian legislation, establishing a maximum value of $200 \mathrm{mg} / \mathrm{L}$ of total $\mathrm{SO}_{2}$ in wines of fresh fruit (30). High total phenolics content was verified in the wine (199.25 mg GAE/L), however, it is noticeable reduction of such content when compared to values found in fruit in natura (1702.0 and $983.4 \mathrm{mg}$ GA/100g, Table 1). This reduction may be related to the fact of the blackberry must have been formulated with the pulp of the fruit, without seeds and with reduced quantity of husks. In fact, the largest contents of polyphenols are commonly found in the husks and seeds on the fruit.

Budak and Guzel-Seydim (14) when evaluated the content of total phenolic compounds in wine derived from Ulugbey Karasi grapes produced in Turkey, found values significantly below $(237 \mathrm{mg}$ GAE/L). On the other hand, Su and Chien (31) verified superior results to those obtained in this study, describing the content of $858 \mathrm{mg}$ GAE/L in blueberry wines fermented without bark and 1150 $\mathrm{mg}$ GAE/L in fermented wines with bark. Such results indicate that the presence of bark in must during alcoholic fermentation, can contribute to greater content of total phenolic compounds in wine produced.

Similarly to that observed with the content of polyphenols, occurred decrease in the content of anthocyanins present in the wine $(51.93 \mathrm{mg}$ cyanidin 3-glucoside /L) in relation to fruit (511.7 and $399.4 \mathrm{mg}$ cyanidin 3-glucoside /L), as shown in Tables 1 and 2. In the same way, Mena et al. (32) reported content between $1360 \mathrm{mg}$ cyanidin 3glucoside /L and $230 \mathrm{mg}$ cyanidin 3 -glucoside / $\mathrm{L}$ in pomegranate juice from variety wonderful and Mollar Elche, however, when carrying out the winemaking such compounds have reduced $46 \%$ and $61 \%$, respectively.

The tests for assessing free radicals scavenging capacity by methods DPPH and $\mathrm{ABTS}^{+}$ demonstrated that the blackberry wine presents antioxidant activity. The antioxidant activity of the product is associated with the presence of polyphenolic compounds, flavonoid and anthocyanins, among other bioactive compounds from the fruit.

Blackberry wine presented an antioxidant potential, measured in trolox equivalent, of $139.52 \mu \mathrm{mol}$ $\mathrm{TE} / \mathrm{L}$ by the DPPH method and $21.24 \mathrm{mmol} \mathrm{TE} / \mathrm{L}$ by the $\mathrm{ABTS}^{+}$method. Budak and Guzel-Seydim (14) verified lower values in red grapes wine from variety Ulugbey Karasi, when assessing the antioxidant capacity by the $\mathrm{ABTS}^{+}$method. Such authors describe values of $11.20 \mathrm{mmol} \mathrm{TE} / \mathrm{L}$. On the other hand, Mulero et al. (33) to evaluate the antioxidant activity (ABTS method) of wines from traditional and organic grapes observed activities of $6.78 \mathrm{mmoL} \mathrm{TE} / \mathrm{mL}$ in organic grapes wine and 6.02 $\mathrm{mmol} / \mathrm{mL}$ in traditional grapes wine.

\section{Acetic oxidation and characterization of blackberry vinegar}

As can be seen in Figure 3, the inoculum composed of acetic acid bacteria isolated from colonial vinegar, demonstrated efficiency in conversion of ethanol to acetic acid. Good microbial performance was verified over the three successive cycles of alcohol-acetic acid transformation. 


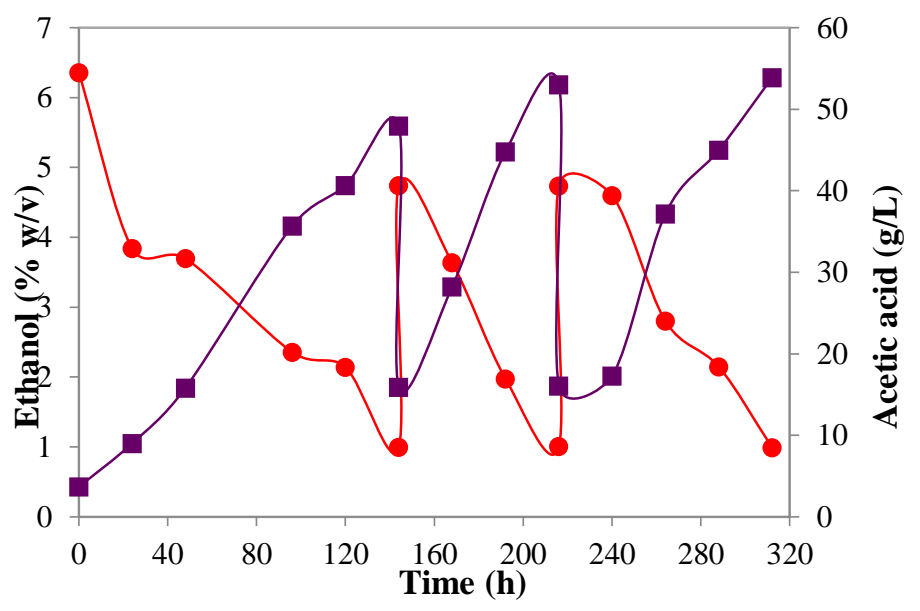

Figure 3 - Content of ethanol (•) and acetic acid (-) along the cycles of acetic acid transformation.

The first cycle had duration of $144 \mathrm{~h}$, when ethanol consumption was of $85 \%$ of the content present in wine and the acetic acid production was of $47.9 \mathrm{~g} / \mathrm{L}$ (Fig. 3 and Table 3). Already in the second cycle, considerable reduction in time of conversion was observed $(72 \mathrm{~h})$ and production of $52.9 \mathrm{~g} / \mathrm{L}$ acetic acid and $78.8 \%$ substrate consumption.

The reduction in the fermentation time in $50 \%$ in the second cycle in relation to the first may be associated to a higher amount of acetic acid bacteria inside the barrel. In fact, in the second cycle of fermentation, had already complete formation of superficial film, known as mother of vinegar. This film is formed by polysaccharides and facilitates the contact of acetic acid bacteria with superficial oxygen. Possibly in the first cycle of fermentation, due to absence of this initial film, which is formed along the process of acetic acid transformation, there was lower efficiency in acetic oxidation by bacteria.

However, in the third cycle time of acetic acid transformation increased to 96 hours with production of $53.84 \mathrm{~g} / \mathrm{L}$ acetic acid and $79.1 \%$ substrate consumption. Possibly, the increase in the time of conversion in the third cycle in relation to the second, may be associated with possible excessive accumulation of biomass and acetic acid bacteria in superficial gelatinous layer with a consequent reduction in the transfer and absorption of oxygen by acetic acid bacteria, having as a consequence some reduction in oxidative conversion of ethanol to acetic acid. It is important to highlight that in the vinegar production the availability of oxygen is a limiting factor in the process of acetic acid transformation (34).
A physical-chemical parameter of great importance to the quality of vinegars is the acidity. Vinegars with acidity less than $4 \%$ may suffer anguillulas infections (vinegar eels) and on the other hand, vinegar with acidity exceeding $5.5 \%$ can submit as products very acid and are rejected by the consumers. In the present study, the acidity varied from $4.09 \mathrm{~g} / 100 \mathrm{~mL}$ in the first cycle to $4.91 \mathrm{~g} / 100$ $\mathrm{mL}$ in the third cycle of acetic acid transformation, values that indicate adequate acetic acid transformation and obtaining product with good acidity.

The total soluble solids content remained constant in 3 cycles of acetic acid transformation ( $\left.5^{\circ} \mathrm{Brix}\right)$, being verified small reduction of solids in relation to blackberry wine $\left(6^{\circ} \mathrm{Brix}\right)$. Such reduction in the levels of soluble solids may be related to the possible consumption of residual sugars present in alcoholic fermented (wine) during the acetic oxidation.

Brazilian legislation establishes that fruit vinegars must contain at least $1 \mathrm{~g} / \mathrm{L}$ and a maximum of $5 \mathrm{~g} / \mathrm{L}$ of fixed mineral residue; in this sense all vinegar produced present suitable values. The total dry extract parameter demonstrates the content of mineral and organic materials that remain after the evaporation of water and other volatile substances of vinegar. The values found are consistent with vinegar produced the basis of fruit pulps and evidence the quality of vinegar obtained.

With relation to the content of sulphates, vinegars of fruit must contain at most $1 \mathrm{~g} / \mathrm{L}$ (35). The values found in the three consecutive batches were well below $(0.026 \mathrm{~g} / \mathrm{L})$, being therefore within the limit established by legislation. Another important aspect 
and defined by the Brazilian legislation is that fruit vinegars must not exceed $1 \%$ (v/v) alcohol content. According to data described on Table 3, the values obtained in three cycles are in line with the legislation (between 0.93 and $0.95 \mathrm{~g} / \mathrm{L}$ ).

Considerable quantities of phenolic compounds were verified in the vinegar obtained in three cycles of acetic acid transformation (138.95 mg GAE/L; $151.8 \mathrm{mg} \mathrm{GAE} / \mathrm{L}$ and $165.2 \mathrm{mg} \mathrm{GAE} / \mathrm{L})$. It is interesting to note that there was little reduction of total phenolics content derived from of wine (199.25 mg GAE/L, Table 2) in vinegars produced. The content of phenolic compounds present in vinegars indicates that there was no significant losses of such compounds by oxidation during acetic acid transformation. In this sense, Ubeda et al. (22), point out that the limited exchange of oxygen during acetic acid transformation by slow process of acetic acid transformation (Orleans method), contributes to minors losses of such compounds by oxidation in relation to processes that use injection of air.

On the other hand, a noticeable reduction of phenolic compounds in wine compared to the quantities originally present in fruit was verified (ethanolic extract: $983.4 \mathrm{mg}$ GAE/100g; acetone extract: $1702.00 \mathrm{mg} \mathrm{GAE} / 100 \mathrm{~g}$ ). The reduction of the content of the phenolic compounds in wine in comparison to that seen in fruit, can be justified by the fact of fruit have been analyzed in its full form, i.e. with bark and seeds that are parts of fruit rich in phenolic substances.

Similarly, there was a reduction of total anthocyanins content on wine (51.93 mg cyanidin3 -glucoside/L) in relation to the one verified in fruit (511.7 and $399.4 \mathrm{mg}$ cyanidin-3-glucoside/100g). It was also verified reductions of anthocyanins content (1st cycle: $49.8 \%$; 2 nd cycle: $34.5 \%$ and $3 \mathrm{rd}$ cycle: $14 \%$ ) in vinegar obtained in different cycles with regard to wine.

However, although it was observed a reduction of total anthocyanins content, the contents present in vinegar are appreciable (1st cycle: $26.05 ; 2$ nd cycle: 34.0 and 3rd cycle: $32.78 \mathrm{mg}$ cyanidin 3 -glucoside /L). Su and Chien (31) verified lower anthocyanins content in blueberry vinegar produced from fermented wines without bark $(9.7 \mathrm{mg}$ cyanidin 3glucoside /L) and with bark (32.2 mg cyanidin 3glucoside/L).

Several studies evaluating the antioxidant capacity of different fruits are reported in the scientific literature. However, there are few reports evaluating the antioxidant potential in fruit vinegars. The results of the tests of antioxidant activity in vitro, described in Table 3 demonstrate that the blackberry vinegars showed significant ability to scavenge DPPH and $\mathrm{ABTS}^{+}$radicals. Similar values of DPPH radical scavenging ability were verified in the vinegar produced in three cycles of acetic acid transformation (1st cycle: $103.5 \mu \mathrm{mol} \mathrm{TE} / \mathrm{mL}$, 2nd cycle: $107.35 \mu \mathrm{mol}$ $\mathrm{TE} / \mathrm{mL}$ and 3rd cycle: $107.73 \mu \mathrm{mol} \mathrm{TE} / \mathrm{mL})$. Such values are higher than those found by Budak and Guzel-Seydim (14) in grape vinegar $(13.50 \mu \mathrm{mol}$ $\mathrm{TE} / \mathrm{mL}$ ). Ubeda et al. (22) described values between $3227 \mu \mathrm{mol} \mathrm{TE} / \mathrm{kg}$ and $3388 \mu \mathrm{mol} \mathrm{TE} / \mathrm{kg}$ in strawberry vinegar.

The $\mathrm{ABTS}^{+}$radical scavenging ability verified in three samples of vinegars were also similar between themselves. In the first cycle, the antioxidant activity front to the radical $\mathrm{ABTS}^{+}$was 15.63 $\mathrm{mmol} / \mathrm{L}$, in the second was $17.36 \mathrm{mmol} / \mathrm{L}$ and in the third cycle was $19.03 \mathrm{mmol} / \mathrm{L}$.

Comparing the results of the DPPH and $\mathrm{ABTS}^{+}$ radicals scavenging ability of wine and vinegar produced is verified some reduction in the antioxidant potential. There was a reduction in DPPH radical scavenging ability between $22.8 \%$ (3rd cycle) and $25.8 \%$ (1st cycle). With relation to $\mathrm{ABTS}^{+}$radical scavenging ability the percentage in the reduction of antioxidant activity varied from $10.4 \%$ (3rd cycle) and $26.4 \%$ (1st cycle).

\section{CONCLUSIONS}

The blackberry fruits studied presented commercial quality and physical-chemical characteristics similar to cultivars produced in other Brazilian regions. The fruits are highlighted by nutritional values, especially by the content of sugars, fibers, total phenolics and antioxidant potential. The high content of sugars make the blackberry an attractive fruit for the winemaking and production of vinegar and obtaining such products can circumvent problems of loss due to high perishability and fragility of the fruit.

Industrial yeast used in alcoholic fermentation has shown efficiency in the process, being produced blackberry wine with pleasant aroma and taste. Were verified alcoholic fermentation yield of 0.39 $\mathrm{g} / \mathrm{g}$, volumetric productivity in ethanol of 1.78 g/L.h and efficiency of $76 \%$. Inoculum composed of acetic acid bacteria isolated from colonial vinegar was effective in acetic acid transformation, with maintenance of the efficiency of the process in successive cycles of acetic acid transformation. 
Vinegars produced presented physical-chemical parameters of quality consistent with Brazilian legislation, as well as appreciable contents of phenolic compounds, anthocyanins and antioxidant potential.

The production of blackberry vinegar in wood barrel (slow process) can be a good option of income for family producers, considering the hardiness of fruit cultivation, the simplicity of the vinegar production process and the possibility of value aggregation to the productive chain.

\section{ACKNOWLEDGEMENTS}

The authors thanks to CAPES, CNPq and Araucaria Foundation for financial support.

\section{REFERENCES}

1. Fredes C, Yousef GG, Robert P, Grace MH, Lila MA, Gómez M, et al. Anthocyanin profiling of wild maqui berries (Aristotelia chilensis [Mol.] Stuntz) from different geographical regions in Chile. J Sci Food Agric. 2014;94(13):2639-48.

2. Ivanovic J, Tadic V, Dimitrijevic S, Stamenic M, Petrovic S, Zizovic I. Antioxidant properties of the anthocyanin-containing ultrasonic extract from blackberry cultivar "Cacanska Bestrna." Ind Crops Prod. 2014;53:274-81.

3. Gancel AL, Feneuil A, Acosta O, Pérez AM, Vaillant F. Impact of industrial processing and storage on major polyphenols and the antioxidant capacity of tropical highland blackberry (Rubus adenotrichus). Food Res Int. 2011;44(7):2243-51.

4. Azofeifa G, Quesada S, Pérez AM, Vaillant F, Michel A. Pasteurization of blackberry juice preserves polyphenol-dependent inhibition for lipid peroxidation and intracellular radicals. $J$ Food Compos Anal. 2015;42:56-62.

5. Kaume L, Howard LR, Devareddy L. The blackberry fruit: A review on its composition and chemistry, metabolism and bioavailability, and health benefits. J Agric Food Chem. 2012;60(23):5716-27.

6. Joo, M., Lewandowski, N., Auras, R., Harte, J., Almenar E. Comparative study of blackberry fruit in bio-based and petroleum-based containers under retail storage conditions. Food Chem. 2011;26:173440.

7. Kumar B, Smita K, Cumbal L, Debut A, Angulo Y. Biofabrication of copper oxide nanoparticles using Andean blackberry ( Rubus glaucus Benth.) fruit and leaf. J Saudi Chem Soc. 2015;1-6.

8. Ory I, Romero E, Cantero D. Optimum Starting-up Protocol of a pilot plant scale acetifier for vinegar production. J Food Eng. 2002;52:31-7.
9. AOAC. Official Methods of Analysis of AOAC International. Assoc of Anal Chem Int. 2007;CD ROM.

10. Miller GL. Use of Dinitrosalicylic acid reagent for determination of reducing sugar. Anal Chem. 1959;31(3):426-8.

11. Singleton VL, Orthofer R, Lamuela-Raventós RM. Analysis of total phenols and other oxidation substrates and antioxidants by means of folinciocalteu reagent. Methods Enzymol. 1998;299:15278.

12. Lee J, Durst RW, Wrolstad RE. Determination of total monomeric anthocyanin pigment content of fruit juices, beverages, natural colorants, and wines by the $\mathrm{pH}$ differential method: Collaborative study. $J$ AOAC Int. 2005;88(5):1269-78.

13. Brand-Williams W, Cuvelier ME, Berset C. Use of a free radical method to evaluate antioxidant activity. LWT - Food Sci Technol. 1995;28(1):25-30.

14. Budak HN, Guzel-Seydim ZB. Antioxidant activity and phenolic content of wine vinegars produced by two different techniques. J Sci Food Agric. 2010;90(12):2021-6.

15. Souza VR, Pereira PAP, da Silva TLT, de Oliveira Lima LC, Pio R, Queiroz F. Determination of the bioactive compounds, antioxidant activity and chemical composition of Brazilian blackberry, red raspberry, strawberry, blueberry and sweet cherry fruits. Food Chem. 2014;156:362-8.

16. Hirsch GE, Facco EMP, Rodrigues DB, Vizzotto M, Emanuelli T. Caracterização físicoquímica de variedades de amora-preta da região sul do Brasil. Ciência Rural. 2012;42:942-7.

17. Wu R, Frei B, Kennedy J a., Zhao Y. Effects of refrigerated storage and processing technologies on the bioactive compounds and antioxidant capacities of "Marion" and "Evergreen" blackberries. LWT Food Sci Technol. 2010;43(8):1253-64.

18. Işik E, Şahin S, Demir C, Türkben C. Determination of total phenolic content of raspberry and blackberry cultivars by immobilized horseradish peroxidase bioreactor. $J$ Food Compos Anal. 2011;24(7):944-9.

19. Flores FP, Singh RK, Kerr WL, Pegg RB, Kong F. Total phenolics content and antioxidant capacities of microencapsulated blueberry anthocyanins during in vitro digestion. Food Chem. 2014;153:272-8.

20. Pergola C, Rossi A, Dugo P, Cuzzocrea S, Sautebin L. Inhibition of nitric oxide biosynthesis by anthocyanin fraction of blackberry extract. Nitric Oxide - Biol Chem. 2006;15(1):30-9.

21. Vizzotto M, Pereira MC. Blackberry (Rubus sp.): Extraction process optimization and determination of phenolic compounds antioxidants. Rev Bras Frutic. 2011;33(4):1209-14.

22. Ubeda C, Callejón RM, Hidalgo C, Torija MJ, Troncoso a. M, Morales ML. Employment of different processes for the production of strawberry 
vinegars: Effects on antioxidant activity, total phenols and monomeric anthocyanins. LWT - Food Sci Technol. 2013;52(2):139-45.

23. Siriwoharn T, Wrolstad RE. Polyphenolic composition of marion and evergreen blackberries. $J$ Food Sci. 2004;69(4):233-40.

24. Hong-Guang Y, When-Hua Z, Jiang-Hua C, Zhi-En D.. Optimization of the alcoholic fermentation of blueberry juice by AS 2.316 Saccharomyces cerevisiae wine yeast. African $J$ Biotechnol. 2012;11(15):3623-30.

25. Jagtap UB, Waghmare SR, Lokhande VH, Suprasanna P, Bapat VA. Preparation and evaluation of antioxidant capacity of Jackfruit (Artocarpus heterophyllus Lam.) wine and its protective role against radiation induced DNA damage. Ind Crops Prod. 2011;34(3):1595-601.

26. Jeong JH, Jung H, Lee SR, Lee HJ, Hwang KT, Kim TY. Anti-oxidant, anti-proliferative and antiinflammatory activities of the extracts from black raspberry fruits and wine. Food Chem. 2010;123(2):338-44.

27. Sun SY. Evaluation of different Saccharomyces cerevisiae strains on the profile of volatile compounds and polyphenols in cherry wines. Food Chem. 2011;127:547-55.

28. Coelho E, Vilanova M, Genisheva Z, Oliveira JM, Teixeira J a., Domingues L. Systematic approach for the development of fruit wines from industrially processed fruit concentrates, including optimization of fermentation parameters, chemical characterization and sensory evaluation. LWT - Food Sci. Technol. 2015;62(2):1043-52.

29. Oliveira MES, Pantoja L, Duarte WF, Collela CF, Valarelli LT, Schwan RF, et al. Fruit wine produced from cagaita (Eugenia dysenterica DC) by both free and immobilised yeast cell fermentation. Food Res Int. 2011;44(7):2391-400.

30. Brasil. Ministério da Saúde. Agência Nacional de Vigilância Sanitária. 2013. Resolução-RDC, número 5. Aprova o uso de aditivos alimentares com suas respectivas funções e limites máximos para bebidas alcoólicas (exceto as fermentadas). Diário Oficial da União, Poder Executivo, Brasília, 2013 p. Seção 1, 43.

31. Su MS, Chien PJ. Antioxidant activity, anthocyanins, and phenolics of rabbiteye blueberry (Vaccinium ashei) fluid products as affected by fermentation. Food Chem. 2007;104(1):182-7.

32. Mena P, Gironés-Vilaplana A, Martí N, GarcíaViguera C. Pomegranate varietal wines: Phytochemical composition and quality parameters. Food Chem. 2012;133(1):108-15.

33. Mulero J, Pardo F, Zafrilla P. Antioxidant activity and phenolic composition of organic and conventional grapes and wines. J Food Compos Anal. 2010;23(6):569-74.

34. Qi Z, Yang H, Xia X, Xin Y, Zhang L, Wang
$\mathrm{W}$, et al. A protocol for optimization vinegar fermentation according to the ratio of oxygen consumption versus acid yield. J Food Eng. 2013;116(2):304-9.

35. Brasil. Ministério da Agricultura, Pecuária e Abastecimento. 2012. Instrução Normativa número 6: Estabelece os padrões de identidade e qualidade e a classificação dos fermentados acéticos. Diário Oficial da União, Poder Executivo, Brasília, DF, 04 de abril de 201. 2012.
Received: March 02, 2016; Accepted: April 26, 2016 


\section{BRAZILIAN ARCHIVES OF BIOLOGY AND TECHNOLOGY}

AN INTERNATIONAL JOURNAL

\section{Erratum}

In Article "Blackberry Vinegar Produced By Successive Acetification Cycles: Production, Characterization And Bioactivity Parameters", with the number of DOI: http://dx.doi.org/10.1590/1678-4324-2016150136, published in journal Brazilian Archives of Biology and Technology, vol. 59, the 06 page.

To include:

Table 2. Physical-chemical characterization and bioactivity parameters of blackberry wine.

\begin{tabular}{lc}
\hline \multicolumn{1}{c}{ Physical-chemical parameters } & Observed values \\
\hline $\mathrm{pH}$ & 3.18 \\
Titratable acidity $(\mathrm{g} / 100 \mathrm{~mL})$ & $0.92 \pm 0.004$ \\
Total SolubleSolids $\left({ }^{\circ} \mathrm{Brix}\right)$ & $6 \pm 0.00$ \\
Ethanol $(\%, \mathrm{v} / \mathrm{v})$ & $8.9 \pm 0.1$ \\
Total reducing sugar $(\mathrm{g} / \mathrm{L})$ & $52.4 \pm 0.002$ \\
Density at $20^{\circ} \mathrm{C}(\mathrm{g} / \mathrm{mL})$ & $1052.8 \pm 0.00$ \\
Free sulfur dioxide $-\mathrm{SO}_{2}(\mathrm{mg} / \mathrm{L})$ & $15.32 \pm 0.002$ \\
Total sulfur dioxide $-\mathrm{SO}_{2}(\mathrm{mg} / \mathrm{L})$ & $40.96 \pm 0.004$ \\
Total phenolic compounds $(\mathrm{mg}$ GAE/L) & $199.25 \pm 2.19$ \\
Anthocyanins $(\mathrm{mg}$ cyanidin-3-glucoside/L) & $51.93 \pm 0.53$ \\
Antioxidant activity $-\mathrm{DPPH}(\mu \mathrm{mol} \mathrm{TE} / \mathrm{mL})$ & $139.52 \pm 7.07$ \\
Antioxidant activity $-\mathrm{ABTS}(\mathrm{mmol} \mathrm{TE} / \mathrm{L})$ & $21.24 \pm 1.24$ \\
\hline
\end{tabular}

GAE: gallic acid equivalent

TE: trolox equivalent

In the 08 page, to include:

Tabela 3. Physical-chemical characterization and bioactivity parameters of blackberry vinegar produced in barrel of brazilian gold wood.

\begin{tabular}{lccc}
\hline \multicolumn{1}{c}{ Parameters analyzed } & \multicolumn{3}{c}{ Observed values } \\
\cline { 2 - 4 } & $\mathbf{1}^{\text {st }}$ cycle & $\mathbf{2}^{\text {nd }}$ cycle & $\mathbf{3}^{\text {rd }} \mathbf{c y c l e}^{\mathrm{a}}$ \\
\hline Acetic acid production $(\mathrm{g} / \mathrm{L})$ & $47.9 \pm 5.0^{\mathrm{a}}$ & $52.9 \pm 1.82^{\mathrm{a}}$ & $53.84 \pm 0,31^{\mathrm{a}}$ \\
Ethanol consumption $(\%)$ & $85 \pm 1.86^{\mathrm{a}}$ & $78.8 \pm 5.28^{\mathrm{a}}$ & $79.8 \pm 2.42^{\mathrm{a}}$ \\
$\mathrm{pH}$ & $2.62 \pm 0.0^{\mathrm{b}}$ & $2.63 \pm 0.0^{\mathrm{b}}$ & $2.7 \pm 0.01^{\mathrm{a}}$ \\
Titratable acidity $(\mathrm{g} / 100 \mathrm{~mL})$ & $4.09 \pm 0.08^{\mathrm{c}}$ & $4.53 \pm 0.02^{\mathrm{b}}$ & $4.91 \pm 0.41^{\mathrm{a}}$ \\
Total soluble solids $\left({ }^{\circ} \mathrm{Brix}\right)$ & $5.0 \pm 0.0^{\mathrm{a}}$ & $5.0 \pm 0.0^{\mathrm{a}}$ & $5.0 \pm 0.0^{\mathrm{a}}$ \\
Mineral residue $(\mathrm{g} / \mathrm{L})$ & $3.73 \pm 0.0^{\mathrm{b}}$ & $3.9 \pm 0.05^{\mathrm{a}}$ & $3.74 \pm 0.0^{\mathrm{b}}$
\end{tabular}


Total dry extract $(\mathrm{g} / \mathrm{L})$

Dry reduced extract $(\mathrm{g} / \mathrm{L})$

Density at $20^{\circ} \mathrm{C}(\mathrm{g} / \mathrm{mL})$

Sulphates $(\mathrm{g} / \mathrm{L})$

Ethanol (g/L)

Total phenolics (mg GAE/L)

Anthocyanins (mg/L)

Antioxidant activity - DPPH $(\mu \mathrm{mol}$ $\mathrm{TE} / \mathrm{mL})$

Antioxidant activity - ABTS (mmol TE/L)

${ }^{a, b, c, c}$ Different letters, in the same line, are significantly different to each other $(\mathrm{p}<0.05)$. GAE: gallic acid equivalent, TE: trolox equivalent.

\begin{tabular}{ccc}
$44.3 \pm 0.04^{\mathrm{a}}$ & $33.3 \pm 0.05^{\mathrm{b}}$ & $32.0 \pm 0.21^{\mathrm{c}}$ \\
$15.68 \pm 0.06^{\mathrm{c}}$ & $26.69 \pm 0.06^{\mathrm{b}}$ & $26.98 \pm 0.01^{\mathrm{a}}$ \\
$1077.3 \pm 0.11^{\mathrm{a}}$ & $1077.8 \pm 0.05^{\mathrm{a}}$ & $1077.7 \pm 0.05^{\mathrm{a}}$ \\
$0.026 \pm 0.0^{\mathrm{a}}$ & $0.026 \pm 0.0^{\mathrm{a}}$ & $0.026 \pm 0.0^{\mathrm{a}}$ \\
$0.95 \pm 0.08^{\mathrm{a}}$ & $0.94 \pm 0.090^{\mathrm{a}}$ & $0.93 \pm 0.07^{\mathrm{a}}$ \\
$138.95^{\mathrm{b}}$ & $151.8^{\mathrm{b}}$ & $165.2^{\mathrm{a}}$ \\
$26.05 \pm 0.35^{\mathrm{a}}$ & $34.23 \pm 0.46^{\mathrm{a}}$ & $32.78 \pm 0.56^{\mathrm{a}}$ \\
$103.5 \pm 2.35^{\mathrm{a}}$ & $107.35 \pm 5.95^{\mathrm{a}}$ & $107.73 \pm 5.95^{\mathrm{a}}$ \\
$15.63 \pm 0.95^{\mathrm{c}}$ & $17.36 \pm 0.99^{\mathrm{b}}$ & $19.03 \pm 0.99^{\mathrm{a}}$ \\
\hline
\end{tabular}

